\section{Oecophorid (Micro Lepidoptera) diversity from Shivalik hills of northwestern Himalaya}

\section{P.C. Pathania ${ }^{1}$, Rachita Sood ${ }^{2} \&$ H.S. Rose ${ }^{3}$}

1 Department of Entomology, Punjab Agricultural University, Ludhiana, Punjab 141004, India

2 Department of Zoology, Guru Nanak (PG) Girls College, Mode Town, Ludhiana, Punjab 141002, India

${ }^{3}$ Department of Life Sciences, Lovely Professional University, Jalandhar, Punjab 144003, India

E-mail: 1 pathaniapc@yahoo.co.in

Abbreviations: $1 A$ - First anal vein; $2 A$ - Second anal vein; $3 A$ - Third anal vein; $1 A+2 A$ - Vein representing fused first and second anal vein; CuA1 - First cubital vein; CuA2 - Second cubital vein; CuP - Cubital posterior vein; M1 - First median vein; M2 - Second median vein; M3 - third median vein; R1 - First radial vein; R2 - Second radial vein; R3 - Third radial vein; R4 - Fourth radial vein;R5 - Fifth radial vein; Rs Radial sector; Sc - Subcostal vein; Sc+R1 - Stalk of subcostal and first radial vein.

Family Oecophoridae belongs to the superfamily Gelechioidea, which includes mostly small moths. The moths of this family have vertex and frons covered with smooth scales, antenna filiform, longer than half the length of forewing; labial palpus long, upturned; male genitalia with gnathos broader at base, unarticulated, tapering to slender or rounded apex. The elevation of the Shivalik range extends up to $1500 \mathrm{~m}$ above m.s.l., and is demarcated by the Kali River in Uttarakhand and the Indus in Jammu and Kashmir (Fig. 1) (Chitkara 1998). The authors undertook survey-cum-collection tours to localities including Kangra, Palampur, Dharamshala, Tanyhar, Sarkaghat, Baijnath, Andhretta, Solan, Dharampur, Nauni, Sabathu, Renuka lake, Nahan, Paunta Sahib (Himachal Pradesh), Jammu, Katra, Mansar Lake (Jammu \& Kashmir),

Date of online publication 26 July 2009

ISSN 0974-7907 (online) | 0974-7893 (print)

Editor: R.K. Varshney

\section{Manuscript details:}

Ms \# 01984

Received 23 April 2008

Final received 23 June 2009

Finally accepted 25 June 2009

Citation: Pathania, P.C., Rachita Sood \& H.S. Rose (2009). Oecophorid (Micro Lepidoptera) diversity from Shivalik hills of northwestern Himalaya. Journal of Threatened Taxa 1(7): 385-391.

Copyright: (C) P.C. Pathania, Rachita Sood \& H.S. Rose 2009. Creative Com mons Attribution 3.0 Unported License. JoTT allows unrestricted use of this article in any medium for non-profit purposes, reproduction and distribution by providing adequate credit to the authors and the source of publication.

Acknowledgement: We are thankful to the Ministry of Environment and Forests (GOI), New Delhi, and Department of Science and Technology, New Delhi for funding the projects on moths and to the ViceChancellor, Punjabi University, Patiala and Punjab Agricultural University, Ludhiana for providing necessary facilities to run the projects. We also thank to Dr. V.V. Ramamurthy, Principal Scientist, Division of Entomology, I.A.R.I., New Delhi for giving permission to visit National Pusa Collection and valuable suggestions during the course of these studies.

\section{OPEN ACGESS | FREE DOWNLOAD}

Dehradun, Haridwar, Vikasnagar (Uttarakhand), Kalka, Pinjore (Haryana), Pathankot, Hoshiarpur, Dasua, Dhar, Roopnagar, Dunera, Mirzapur, Nawanshahar and Anandpur (Punjab) during different seasons from November, 1997 to November, 2001, representing the Shivaliks hills of northwestern Himalaya. The present studies were undertaken to remedy negligence in the study of Microlepidoptera in India due to their small size.

\section{Methodology}

Adults were collected during the night time with the help of portable light traps. Specimens were also collected by hanging a source of light (125 - Watt mercury vapour lamp) on a white sheet or white washed wall. The collected Oecophorid moths were killed using 1,1,2,2, tetrachloro ethane or ethyl acetate. The methodology discussed by Lindquist (1956), Tagestad (1974), Zimmerman (1978), Mikkola (1986) and Landry \& Landry (1994) was followed for the pinning, stretching and preservation of specimens. For study of wings and genitalia standard techniques given by Zimmerman (1978) and Robinson (1976), respectively, have been followed. To study the taxonomic descriptions on various morphological characters (Robinson 1976; Park 1995; Hodges 1998), wing venation (Common 1970; Zimmerman 1978) and external genitalia (Klots 1970), were consulted. Illustrations and diagrams were made using a Camera Lucida attached to a stereoscopic light microscope. Colour photographs of all the species were taken before dissection.

\section{Observations}

Preliminary sorting and taxonomic segregation was done with the help of literature (Meyrick 1894, 1905, 1907, 1908, 1908a, 1909, 1910, 1911, 1912-1916,1913, 1914, 1916-1923, 1923-1930, 1930-1936, Fletcher 1921, 1929; Gaede 1937; Diakonoff 1952, 1954; Janse 1954; Roonwal et al. 1964; Clarke 1955,1965, 1969; Gaedike 1967; Hodges 1978; Moriuti et al. 1985; Nye \& Fletcher 1991; Robinson et al. 1994; Hampson 1992, 1994, 1995, 1996; Lovovsky 1996; Ueda \& Moriuti 1996). Holotypes of the new species have been deposited in the Lepidoptera Laboratory, Department of Zoology, Punjabi University, Patiala. Taxonomic segregation of moths recorded in this study was based on the morphological details as presented below.

\section{Order: Lepidoptera}

\section{Superfamily: Gelechioidea}

Vertex and frons decorated with smooth scales; labial palpus three segmented, upturned, third segment long, acute; forewing with veins $\mathrm{R} 4+\mathrm{R} 5$ stalked; hind tibia with dorsal surface furnished with long slender scales.

\section{Family: Oecophoridae}

Oecophoridae Bruand, 1850, Mem. Soc. Emul. Doubs, (1) 3 (5-6): 45 (as Aecophoridae). Type-genus: Oecophora Latreille, [1796], Précis Caractéres genériques insetes: 146.

Vertex and frons covered with smooth scales; antenna filiform, longer than half the length of forewing; labial palpus long, upturned; male genitalia with gnathos broad basally, unarticulated, tapering to slender or rounded apex 


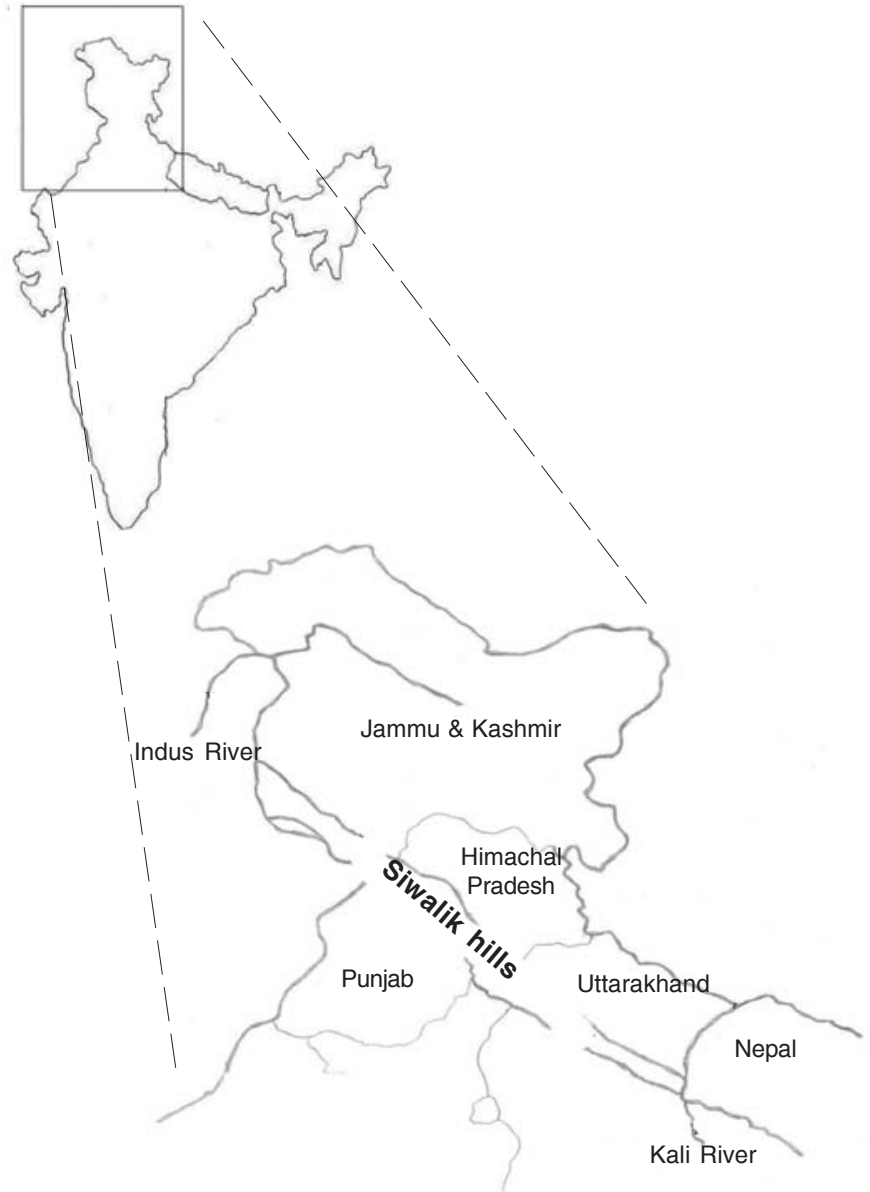

Figure 1. Study area

\section{Subfamily: Autostichinae}

Autostichinae Le Marchand, 1947, Revue fr. Lepidopt., 11: 153.Type-genus: Autosticha Meyrick, 1886, Trans. ent. Soc. Lond., 1886: 281.

Forewing with $\mathrm{CuA} 1$ and $\mathrm{CuA} 2$ stalked or directed posteriorly from cell or separate, $\mathrm{CuP}$ very weak on margin; abdominal tergal setae slender, sometimes deciduous.

\section{Genus: Apethistis Meyrick}

Apethistis Meyrick, 1908, J. Bombay nat. Hist. Soc., 18: 459. Type-species: Apethistis metoeca Meyrick, 1908, ibidem., 18: 460, by original designation.

Vertex and frons dressed with semi-erect scales; labial palpus long, second segment small, scaled, third segment long and acute; antenna long, filiform, about $3 / 4$ length of forewing; legs with erect scales on tibia; forewing with veins R1, R2, R3 free, $\mathrm{R} 4+\mathrm{R} 5$ stalked, $\mathrm{R} 4$ to costa, $\mathrm{R} 5$ to termen, $\mathrm{M} 1$ and $\mathrm{M} 2$ free, $\mathrm{CuA} 1+\mathrm{CuA} 2$ stalked; hindwing with $\mathrm{Rs}+\mathrm{M} 1$ stalked, Rs to costa, M 1 to termen, M3 and $\mathrm{CuA} 1$ connate. Male genitalia with uncus furcate, long, sclerotized, pointed apically; socii absent; gnathos two arms, apex pointed; saccus absent; valva small, broad, costa with a hook-like process, inner surface of cucullus densely setosed; aedeagus rounded basally, swollen; vesica without any cornutus. Female genitalia with ductus bursae centrally placed; corpus bursae ovate in shape; signum present, kidney-shaped.

Description of species recorded in this study are given below under their respective subfamilies.

\section{Apethistis insulsa (Meyrick)}

Brachmia insulsa Meyrick, 1914, J. Bombay nat. Hist. Soc., 22: 774 .

Material examined: 3 males, 2 females, 3.iv.1999; 3 males, 2 females, 22.iv.1999; 12 males, 2 females, 25.iv.1999; 1 female, 17.iv.2000; 11 males, 6 females, 18.iv.2000, Forest Research Institute, Dehradun, Dist. Dehradun, Uttarakhand, 700m; 8 males, 6 females, 26.iv.1999; 2 males, 27.iv.1999, Haridwar, Dist. Dehradun, Uttarakhand, $800 \mathrm{~m}$, coll. P.C. Pathania.

Distribution: India, Pusa (Bengal) (Clarke 1969); Dehradun, Haridwar (Uttarakhand) (present work).

Larval host plant: Unknown

\section{Apethistis metoeca Meyrick}

Apethistis metoeca Meyrick, 1908, J. Bombay nat. Hist. Soc., 18: 460.

Material examined: 1 male, 23.iii.1998; 1 male, 16.iv.1998; 2 males, 11.iii.1999; 1 male, 15.iii.1999; 1 male, 24.iii.1999; 3 males, 2 females, 25.iii.1999; 3 males, 3 females, 27.iii.1999; 1 male, 28.iii.1999; 1 male, 29.iii.1999; 1 male, 1 female, 30.iii.1999; 1 female, 31.iii.1999; Punjabi University, Patiala, Dist. Patiala, Punjab, 250m; 1 female, 6.iv.1999; 1 male, 17.viii.1999; 1 male, 19.viii.1999; 2 males, 24.viii.1999; 1 female, 29.viii.1999; 1 male, 27.ix.1999; 1 male, 12.x.1999; 2 males, 18.x.1999; 1 male, 21.iii.2000; 2 males, 29.iii.2000, Anandpur Sahib, Dist. Ropar, Punjab, 400 m; 2 males, 16.x.1999, Forest Rest House, Chohal, Dist. Hoshiarpur, Punjab, 400m; coll. P.C. Pathania; 3 males, 1 female, 9.xi.2001, Jammu University Campus, Dist. Jammu, Jammu and Kashmir, $350 \mathrm{~m}$, coll. P.C. Pathania and H.S. Rose.

Distribution: Maskeliya (Ceylon) (Clarke 1969); Patiala, Anandpur Sahib, Hoshiarpur (Punjab); Jammu (Jammu \& Kashmir) (present work).

Host plant: Unknown

\section{Subfamily: Xyloryctinae}

Xyloryctinae Meyrick, 1890, Trans. R. Soc. S. Aust., 13: 23 (as Xyloryctidae).

Type-genus: Xylorycta Meyrick, 1890, Trans. R. Soc. S. Aust., 13: 25 (key), 57.

Antenna simple; forewing with CuA1 and CuA2 stalked, forewing with $\mathrm{CuP}$ absent; abdomen with band of spiniform setae on posterior part of terga two to six.

\section{Genus: Cophomantella Fletcher}

Cophomantella Fletcher, 1940, Entomologist's Rec. J. Var., 52: 17.

Vertex and frons beset with smooth scales; labial palpus long, second segment scaled, third segment long and acute; antenna filiform, long, longer than $3 / 4$ length of forewing; abdomen with band of spiniform setae on posterior part of terga two to six, metathoracic leg with small hair like scales on hind tibia; forewing with veins R4+R5 stalked, R5 to costa or apex, R3 absent, M2 absent, $\mathrm{CuA} 1+\mathrm{CuA} 2$ stalked; hindwing with Rs+M1 stalked, Rs to costa, M1 to termen, M2 absent, M3 $+\mathrm{CuA} 1$ stalked, CuP present or vestigial; male genitalia characteristic uncus somewhat thorn-like, long or small; socii absent; gnathos long, apically pointed; saccus absent; juxta concave or parallel distally; valvae elongate, inner surface 
densely setose; aedeagus long and broad; vesica with multishaped cornutus present or absent; female genitalia characteristic anterior apophyses rod-like; antrum broad; ductus bursae centrally broader, sclerotized, coiled near corpus bursae; ductus seminalis open near coiling of ductus bursae; corpus bursae ovate or subovate; signum present.

\section{Cophomantella pumicata (Meyrick)}

Cophomantis pumicata Meyrick, 1929, Exot. Microlepid., 3: 525.

Material examined: 1 male, 22.ix.1999; 2 males, 2 females, 23.ix.1999; 3 males, 18.iv.2000; 4 males, 19.iv.2000, Forest Research Institute, Dehradun, Dist. Dehradun, Uttarakhand, 700m, coll. P.C. Pathania.

Distribution: Bombay, Poona (Clarke, 1965); Dehradun (Uttarakhand) (present work).

Host plant: Unknown.

\section{Cophomantella juxticata Rose and Pathania}

Cophomantella juxticata Rose and Pathania, 2003, Pb. Univ. Res. J (Sci.), 53: 107-108.

Material examined: 1 male, 2 females, 3.iv.1999; 3 males, 4.iv.1999; 2 males, 5.iv.1999; 1 female, 11.iv.1999; 2 males, 2 females, 12.iv.1999, Renuka Lake, Dist. Sirmour, Himachal Pradesh, 740m, coll. P.C. Pathania.

Host plant: Unknown.

\section{Cophomantella lysimopa (Meyrick)} 357.

Cophomantis lysimopa Meyrick, 1933, Exot. Microlepid., 4:

Material examined: 2 males, 10.ix.1998; 3 males, 2 females, 11.ix.1998; 7 males, 11.ix.1999; 5 males, 2 females, 12.ix.1999; 1 male, 14.ix.1999, University of Horticulture and Forestry, Nauni, Dist. Solan, Himachal Pradesh, 1360m; 2 females, 16.ix.1999, Dharampur, Dist. Solan, Himachal Pradesh, 1500m, coll. P.C. Pathania.

Distribution: Bombay, Mahableshwar (Clarke 1965); Nauni, Dharampur (Solan) (present work).

\section{Host plant: Unknown.}

\section{Cophomantella myadelpha (Meyrick)}

Onebala myadelpha Meyrick, 1910, J. Bombay nat. Hist. Soc., 20: 459 .

Cophomantis myadelpha Clarke, 1965, Cat. Type Specimens Microlepid. BMNH described by Edward Meyrick 5: 16.

Material examined: 2 males, 5.vii.1999; 1 male, 11.vii.1999, Tanyhar, Dist. Mandi, Himachal Pradesh, 1120m, coll. P.C. Pathania.

Distribution: Khasi Hills (Assam) (Meyrick 1910); Tanyhar (Himachal Pradesh) (present work).

Host plant: Unknown.

\section{Subfamily: Depressariinae}

Depressariinae Meyrick, 1883, Trans. ent. Soc. Lond., 1883: 123 (as Depressariidae).

Type genus: Depressaria Haworth, 1811, Lepid. Br., 505.

Forewing broad, veins $\mathrm{CuA} 1$ and $\mathrm{CuA} 2$ stalked; hindwing subquadrate, discal cell usually closed, veins Rs and M1 arising separately from cell.

\section{Psorosticha Lower}

Psorosticha Lower, 1901, Trans. R. Soc. S. Aust., 25: 91.

Type-species: Psorosticha acrolopha Lower, 1901, ibidem, 25:

92 , by monotypy.

Vertex and frons decorated with erect scales; labial palpus long, recurved, second segment long, third segment small and acute; antenna long, filiform, longer than $3 / 4$ length of forewing; metathoracic leg with erect scales on hind tibia, forewing with veins $\mathrm{R} 1, \mathrm{R} 2$, R3 free, R4+R5 stalked, R5 to costa, M1, M2, M3 free, $\mathrm{CuA} 1+\mathrm{CuA} 2$ stalked; hindwing subquadrate, with vein Rs to costa, M 1 to termen, M1, M2 free, M3+CuA1 stalked; male genitalia with uncus bilobed, broader at base; socii absent; gnathos turned towards inner surface; tegumen broad, sclerotized; valvae long and broad, setose, sacculus beset with a hook-like process; aedeagus broad; vesica with cornutus present; female genitalia characteristic papillae anales small, sparsely setose; ostium bursae open at side; ductus bursae long, weakly sclerotized; corpus bursae globular in shape; signum lacking.

\section{Psorosticha zizyphi (Stainton)}

Depressaria zizyphi Stainton, 1859, Trans. ent. Soc. Lond., (2) 5: 115.

Psorosticha acrolopha Lower, 1901, Trans. R. S. Aust., 25: 92.

Depressaria angusta Walsingham, 1886, in Moore, Lepid. Ceylon, 3: 508.

Material examined: 1 male, 9.viii.1998; 1 male, 12.iv.1999; 2 females, 4.ix.1999; 1 male, 5.ix.1999, Renuka Lake, Dist. Sirmour, Himachal Pradesh, 740m; 1 female, University of Horticulture and Forestry, Nauni, Dist. Solan, Himachal Pradesh, 1360m; 1 male, Forest Research Institute, Dehradun, Uttarakhand, 700m, 2 males, 12.viii.1999, Punjabi University, Patiala, Dist. Patiala, Punjab, 250m; 2 males, 23.x.2001, Forest Rest House, Dhar, Dist. Gurdaspur, 700m, coll. P.C. Pathania and Rachita Sood.

Distribution: India, Sri Lanka, W. Malaysia, Java, Australia (Robinson et al. 1994); Renuka, Nauni (Himachal Pradesh), Dehradun (Uttarakhand) (present work).

Host plants: Zizyphus jujuba, Citrus, Murraya koenigii (Robinson et al. 1994).

\section{Subfamily: Stathmopodinae}

Stathmopodinae Janse, 1917, Check-List S. Afr. Lepid. Heterocera: 190 (as Stathmopodidae).

Type genus: Stathmopoda Harrich-Schäffer, 1853, Syst. Bearbeitung Schmett. Eur., 5(14) key, 54; 1894, ibidem, 6: Microlepid; pl.9 figs 1722, included in Fletcher 1929 within the Schreckensteiniidae.

Abdominal terga with spiniform setae on posterior margin of each segment; wall of aedeagus with ventro-distal, sclerotized projection in male genitalia.

\section{Stathmopoda Herrich-Schäffer}

Stathmopoda Herrich-Schäffer, 1853, Syst. Bearbeitung Schmett. Eur., 5: 14 (key), 54; 1849, ibidem, 6: Microlepid. pl. 9 figs. 1722.

Type-species: Phalaena pedella Linnaeus, 1761, Fauna Suecica (Edn 2): 367, by subsequent designation by Meyrick 1914, in Wytsman, Genera Insect., 165: 10. 


\section{Stathmopoda auriferella (Walker)}

Gelichia auriferella Walker, 1864, List Specimens Lepid. Insects Colln Br. Mus., 30: 1022. Stathmopoda adulatrix Meyrick, 1917, Exot. Microlepid., 2: 61.

Stathmopoda cirrhaspis Meyrick, 1922, Exot. Microlepid., 2: 585.

Stathmopoda crocophanes Meyrick, 1897, Proc. Linn. Soc. N.S.W., 22: 324.

Stathmopoda divisa Walsingham, 1891, Trans. ent. Soc. Lond., 1891: 121.

Stathmopoda ischnotis Meyrick, 1897, Proc. Linn. Soc. N.S.W., 22: 324 .

Stathmopoda tharsalea Meyrick, 1914, Ann. Transvaal Mus., 4: 199 .

Material examined: 2 males, 10.ix.1998, University of Horticulture and Forestry, Nauni, Dist. Solan, Himachal Pradesh, 1360m; 2 males, 2 females, 16.ix.1999, Dharampur, Dist. Solan, Himachal Pradesh, 1500m; 2 males, 17.vii.1999, Tanyhar, Dist. Mandi, Himachal Pradesh, 1120m; 1 female, 15.vi.2000, Youth Hostel, Ropar, Dist. Ropar, Punjab, coll. P.C. Pathania and Rachita sood.

Distribution: W. Africa to Australa, Thailad, W. Malaysia, Java, Philippines (Robinson et al. 1994); Nauni, Dharampur, Tanyhar (Himachal Pradesh), Ropar (Punjab) (present work). China, Korea, Japan, Sri Lanka, Russia (Far East).

Host plants: Cocos nucifera, Albizia altissiunum (Robinson et al. 1994).

\section{Stathmopoda balanarcha Meyrick}

Stathmopoda balanarcha Meyrick,1916-1923, Exot. Microlepid., 2: 461.

Material examined: 2 males, 24.iii.1998; 1 male, 2.iv.1998; 1 male, 5.ix.1998; 1 female, 15.ix.1998; 1 male, 26.ix.1999; 1 female, 5.x.1999; 1 male, 7.x.1999; 1 female, 24.x.1999; 1 male, 4.v.2000, Punjabi University, Patiala, Dist. Patiala, Punjab, 250m, coll. P.C. Pathania and Rachita sood.

Distribution: Assam, Shillong (Meyrick 1916-1923); Patiala (Punjab) (present work).

Host plant: Unknown

\section{Subfamily: Oecophorinae}

Oecophorinae Bruand, 1850, Mem. Soc. Emul. Doubs (1) 3 (5-6): 45 (as Oecophoridae).

Type-genus: Oecophora Latreille [1796], Précis Caractéres genériques Insectes: 146.

Labial palpus often very slender, long; abdominal terga without spiniform setae or spiniform setae in broad band when present; male genitalia with aedeagus wall without any sclerotized projection.

\section{Genus: Tonica Walker}

Tonica Walker, 1864, List Specimens lepid. Insects Colln Br. Mus., 29: 788.

Type-species: Tonica terasella Walker, 1864, ibidem, 29: 788, by monotypy.

Vertex and frons studded with semi-erect scales; labial palpus small, upturned, second segment small, scaled; third segment long; antenna long, filiform, about $3 / 4$ length of forewing; abdominal terga without spiniform setae; legs with erect scales on hind tibia; forewings with a sinuous costa and scattered tufts of raised scales, vein $\mathrm{R} 2$ absent, $\mathrm{R} 3+\mathrm{R} 4+\mathrm{R} 5$ stalked, arising from a common stalk, R5 arising at the stalking of R4+R5, R4 to costa, R5 to termen, M2 absent, M3+CuA1 stalked; hindwing with Rs+M1 stalked, Rs to costa, M1 to termen, M2 absent, M3+CuA1 stalked; male genitalia characteristic uncus long; socii absent; gnathos present; vinculum U-shaped; saccus absent; valvae small and broad; sacculus prominent, sclerotized, dorsomedially with Y-shaped process; aedeagus broad, sclerotized, vesica with cornutus; female genitalia characteristic papillae anales large, setose; corpus bursae large, irregular in shape, sclerotized; signum present.

\section{Tonica niviferana (Walker)}

Binsitta niviferana Walker, 1864, List Specimens Lepid. Insects Colln Br. Mus., 29: 832.

Material examined: 4 males, 26.vi.1999, Norha Richard Holiday Home, Andhretta, Dist. Kangra, Himachal Pradesh, 900m, coll. P.C. Pathania.

Distribution: Dehradun, Pusa (Roonwal et al. 1964); Andhretta (Himachal Pradesh) (present work).

Host plant: Bombax malabaricum (Fletcher 1921 ).

\section{Tonica zizyphi (Stainton)}

Depressaria zizyphi Stainton, 1859, Trans. ent. Soc. Lond., (2) 5: 115.

Depressaria angusta Walsingham, 1886, in Moore, Lepid. Ceylon, 3: 508.

Psorosticha acrolopha Lower, 1901, Trans. R. Soc. S. Aust., 25: 92.

Material examined: 2 males, 4 females, 4.ix.1999; 2 males, 4.x.1999; 2 males, 6.x.1999; 1 female, 4.xii.1999, Renuka Lake, Dist. Sirmour, Himachal Pradesh 740m; 2 males, 12.ix.1999, University of Horticulture and Forestry, Nauni, Dist. Solan, Himachal Pradesh, 1360m; 1 female, 17.vi.1998, Dharamshala, Dist. Kangra, Himachal Pradesh, 1200m; 1 female, 21.x.1999, Youth Hostel, Ropar, Punjab, 350m, coll. P.C. Pathania.

Distribution: India, Ceylon (Fletcher 1921); Renuka, Nauni, Dharamshala (Himachal Pradesh), Ropar (Punjab) (present work).

Host plants: Citrus, zizypus and Murraya (Fletcher 1921).

\section{Genus: Periacma Meyrick}

Periacma Meyrick, 1894, Trans. ent. Soc. Lond.: 21.

Type-species: Periacma ferialis Meyrick,1894, ibidem: 21, by original designation.

Vertex and frons decorated with semi-erect scales; labial palpus two segmented in male, upturned, second segment exceptionally long and acute; antenna long, filiform, longer than $3 / 4$ length of forewing; legs with semi-erect scales on tibia; forewing with veins R4+R5 stalked, R5 to termen or apex, M 1 and $\mathrm{M} 2$ free, $\mathrm{CuA} 1$ and $\mathrm{CuA} 2$ free; hindwing with Rs to costa, $\mathrm{M} 1$ and $\mathrm{M} 2$ free, $\mathrm{M} 3$ and $\mathrm{CuA} 1$ connate, $1 \mathrm{~A}+2 \mathrm{~A}$ forked at base; male genitalia with uncus large, broader apically, narrowed basally, sclerotized; socii absent; gnathos with well developed ventral plate, with minute spines; tegumen small or broad, saccus absent; valvae with costa distinct, sclerotized, sacculus prominent with processes distally, cucullus with long, dense setae; aedeagus small, with spine apically, coecum present, vesica without cornutus; female genitalia characteristic papillae anales large, setose; ostium bursae broad, centrally placed; ductus bursae small; corpus bursae large; signum 
Key to the subfamily of the family Oecophoridae

1. Forewing with veins CuA1 and CuA2 stalked. Hindwing with veins Rs and M1 separate, fore and hindwings broad, hindwing subquadrate, discal cell usually closed Hindwing with veins Rs and M1 stalked (rarely separate), fore and hindwings not as above, discal cell rarely open Abdominal terga with spiniform setae on posterior margin of each segment; wall of aedeagus with a ventrodistal projection, the latter sclerotized.

Stathmopodinae

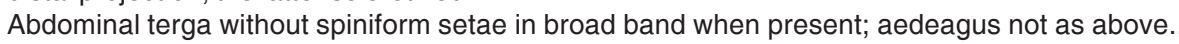

Oecophorinae

\section{Key to the species of the genus Apethistis Meyrick}

1. Forewing with vein Sc ending near middle of costa, vein R4 to costa; hindwing with CuP fully developed; male genitalia with valvae large and broad, aedeagus almost straight upto 3/4th, then narrowed; female genitalia with relatively smaller ostium bursae

insulsa Meyrick Forewing with vein Sc ending at 2/3rd of costa, vein R4 to costa near apex; hindwing with CuP vestigial, visible near anal margin only; male genitalia with valvae small and broad, aedeagus slightly curved near apex, basally bulbous; female genitalia with relatively larger ostium bursae metoeca Meyrick

\section{Key to the species of the genus Cophomantella Fletcher}

1. Forewing with vein R1 originating from center of the discal cell; male genitalia with aedeagus with one of the walls produced into a fine spine, the latter curved pumicata Meyrick Forewing with vein R1 originating from much beyond middle of discal cell; male genitalia with aedeagus not as

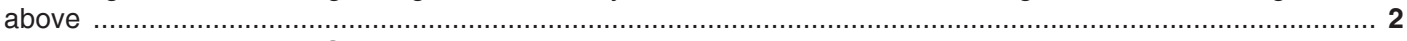

2. Hindwing with veins M3+CuA1 long stalked; male genitalia with each valva broadly tapering, saccular margin somewhat excurved in the basal half, then notched in middle; juxta plate-like, produced into knob like processes, the latter sparsely setose, gnathos relatively small, beak-like juxticata Rose \& Pathania Hindwing with veins M3+CuA1 short stalked; male genitalia with each valva retangular in shape, saccular margin smooth, juxta not as above, gnathos much elongated and produced into fine point apically ................ 3

3. Alar expanse $16-20 \mathrm{~mm}$; hindwing with discal cell closed by arched discocellulars;male genitalia with aedeagus small and broad, apex pointed, vesica lacking cornutus, coecum absent, juxta well developed, long, apically pointed .....

Iysimopa Meyrick Alar expanse $15 \mathrm{~mm}$; hindwing with cell closed by angular discocellulars; male genitalia with aedeagus long and broad, apex rounded, vesica with cornutus, coecum present, juxta reduced, apically rounded.

myadelpha Meyrick

\section{Key to the species of the genus Stathomopoda Herrich-Schäffer}

1. Forewing with Sc ending at $1 / 3$ rd of costa; male genitalia with sacculus apically rounded, cucullus wavy ventro-distally, aedeagus relatively long and broad, apically rounded, vesica with thin, plate-like cornutus; female genitalia with corpus bursae subovate in shape, ductus seminalis open near middle in corpus bursae........... auriferella Walker Forewing with Sc ending at middle of costa; male genitalia with sacculus pointed apically, cucullus convex ventro-distally, aedeagus long and narrowed, apex pointed, vesica with a rod-like broad cornutus; female genitalia with corpus bursae ovate in shape, ductus seminalis open in corpus bursae near ductus bursae .......

balanarcha Meyrick

\section{Key to the genera of the subfamily Oecophorinae}

1. Labial palpus three segmented; forewing with a sinuous costa and scattered tufts of raised scales; male genitalia with gnathos not well developed in respect of ventral plate Tonica Walker Labial palpus two segmented; forewing without sinuous costa and scattered tufts of raised scales; male genitalia with gnathos well developed in respect of ventral platec

Periacma Meyrick

\section{Key to the species of the genus Tonica Walker}

1. Forewing with a black spot near base, one black scale streak and a small triangular spot present near middle of costa, vein Sc joined by a bar at 3/4th with discal cell, CuP visible at anal margin; male genitalia with gnathos small, sacculus with pointed apex exceeding beyond each valva, coecum absent ..................niviferana Walker Forewing maculation not as above, with only one black spot present near base of costa, vein Sc join by a bar at $4 / 5$ th with discal cell, CuP obscure; male genitalia with gnathos long, sacculus with apex not exceeding beyond each valva, coecum present. 


\section{Key to the species of the genus Periacma Meyrick}

1. Forewing with dark fuscous band beyond half of costa join tornus, vein R1 arising at middle of discal cell; hindwing with vein CuP visible near anal margin; male genitalia with valva with saccular margin broad, with two processes apically, costa concave, aedeagus apex with one spine-like process distally, coecum long .....

circumclusa Meyrick

Forewing with dark fuscous band near half of costa join tornus, vein R1 arising at 1/3rd of discal cell; hindwing with vein CuP visible in distal half; male genitalia with valva with saccular margin small, beset with three processes, costa slightly convex, aedeagus apex with two spine-like processes distally, one another near middle, coecum relatively smaller.....

continuata Meyrick

present.

\section{Periacma circumclusa Meyrick}

Periacma circumclusa Meyrick, 1916-1923, Exot. Microlepid., 2: 546 .

Material examined: 8 males, 16.vii.1999, Tanyhar, Dist. Mandi, Himachal Pradesh, 1120 m; 4 females, 23.x.2001, Forest Rest House, Dhar, Dist. Gurdaspur, Punjab, 700m, coll. P.C. Pathania and Rachita Sood.

Distribution: Assam, Sadiya (Meyrick 1916-1923); Tanyhar (Himachal Pradesh), Dhar (Punjab) (present work).

Host plant: Unknown.

\section{Periacma continuata Meyrick}

Periacma continuata Meyrick, 1916-1923, Exot. Microlepid., 2: 546 .

Material examined: 2 males, 24.vi.1999; 2 males, 27.v.2001, Krishi Vishwavidyalaya, Palampur, Dist. Kangra, Himachal Pradesh, 700m; 2 males, 27.vi.1999, Norha Richard Holiday Home, Andhretta, Dist. Kangra, Himachal Pradesh, 900m, Coll. P.C. Pathania.

Distribution: S. India, Palni Hills (Meyrick 1916-1923); Palampur, Andhretta (Himachal Pradesh) (present work).

Host plant: Unknown

\section{Discussion}

Meyrick (1908) proposed the genus Apethistis with A. metoeca Meyrick as its type-species from Ceylon (Maskeliya) in the family Gelechiidae, which was transferred to the family Oecophoridae by Hodges (1978). Out of fourteen species otherwise recorded in this genus, eight i.e., Apethistis sitiens Meyrick (southern India), $A$. cenchritis Meyrick, $A$. consummata Meyrick, A. inspersa Meyrick (Assam), A. officiosa Meyrick (Madras), A. purificata Meyrick (Sikkim), A. superans Meyrick (Kumaon) and $A$. insulsa (Meyrick) (Pusa, Bihar) have been captured from the respective areas of India (Gaede 1937; Clarke 1965). In fact, none of the species has so far been reported from the Shivaliks in North-West India, from where besides the type-species i.e., A. metoeca Meyrick another species i.e., $A$. insulsa (Meyrick) have been collected for the first time.

According to Gaede (1937) and Clarke (1965), the genus Cophomantella Fletcher is represented by fifteen species i.e., elaphopis Meyrick (Khasi Hills), lysimopa Meyrick (Bombay, Mahableshwar), myadelpha (Meyrick) (N. Coorg), osphrantica (Meyrick) (Madras, Palni Hills), pumicata Meyrick (Bombay, Poona), bythota (Meyrick) (Aburi, Goldcost), eremota (Meyrick) (Ceylon), syngonarcha Meyrick (Uganda, Masaka), bifrenata Meyrick (Africa), crypsizyga Meyrick (Nyassaland), cubiculata Meyrick (Seychellen), ephanozona Meyrick (Transvaal), homogramma Meyrick (Natal) and lychnocentra Meyrick (Australian), out of which the former five species belong to
India. In the present field surveys, four species have been captured and reported.

The Oecophorid genus, Periacma Meyrick proposed on the basis of the type-species P. ferialis Meyrick by Meyrick (1894) is unique in having two segmented labial palps in the male. It is mainly distributed in the Oriental Region (Moriuti et al. 1985; Ueda \& Moriuti 1996). While reporting this genus as new to the fauna of Nepal, the latter authors could not get sufficient material as the latter species has been named and described on the basis of a lone male specimen. In the current work, the congeneric nature of the presently studied two species could not be made out on the basis of their female genitalia, as the same has been examined only for one species i.e., $P$. circumclusa Meyrick, yet it can be safely stated that it broadly conforms to that of P. himalayanesis Ueda \& Moriuti (Ueda \& Moriuti 1996). Both the species i.e. P. himalayanesis and $P$. continuata are closer to each other in view of structures such as the lamella antevaginalis, the ductus bursae and the ductus seminalis which originates $1 / 3 \mathrm{rd}$ posteriorly from the ductus bursae in the female genitalia.

\section{Referemces}

Chitkara, M.G. (1998). Encyclopaedia of Ecology, Environment and Pollution, 6: $1-339$.

Clarke, J.F.G. (1955). Catalogue of the Type Specimens of Microlepidoptera in the British Mus. (Natural History) described by Edward Meyrick, Trustees of the British Museum (Natural History), London, Vol. I: 332pp.

Clarke, J.F.G. (1965). Catalogue of the Type Specimens of Microlepidoptera in the British Mus. (Natural History) described by Edward Meyrick, Trustees of the British Museum (Natural History), London, Vol. V: 581pp.

Clarke, J.F.G. (1969). Catalogue of the Type Specimens of Microlepidoptera in the British Mus. (Natural History) described by Edward Meyrick, Trustees of the British Museum (Natural History), London, Vol. VI: 537pp.

Common, I.F.B. (1970). Lepidoptera, pp. 765-866. In: Mackerras, I.M. (ed.). The Insects of Australia. A Textbook for Students and Research Workers. 1st edition. Melbourne University Press, Carlton, Australia. xiii $+1029 p p$.

Diakonoff, A. (1952). Entomological results of Swedish expedition 1934 to Burma and British India. Lepidoptera collected by R. Malaise. Microlepidoptera 1. Arkiv Fur Zoologi 3: 73-79.

Diakonoff, A. (1954). Consideration on the terminology of the genitalia in Lepidoptera. Lepidoptera News 8(3-4): 67-74.

Fletcher, T.B. (1921). Life history of Indian Insects, Microlepidoptera. Memoirs of Department of Agriculture India 6: 1-2 17 .

Fletcher, T.B. (1929). A list of the generic names used for Microlepidoptera. Memoirs of Department of Agriculture., India 11: ix $+246 \mathrm{pp}$.

Gaede, M. (1937). Catalogue of Gelechiidae. Lepidopterorum catalogus, 79: 1630

Gaedike, R. (1967). Zur systematischen Stellung einiger Gattungen der Heliodinidae / Schreckensteiniidae sowie Revision der paläarktischen Arten der Gattung Pancalia Curtis, 1830. (Lepidoptera: Heliodinidae / Schreckensteiniidae). 23 Textfig., 12pp.

Hampson, G.F. (1892). Fauna of British India including Ceylon and Burma, Moths. Vol.I. Taylor and Francis, London, xiii $+527 \mathrm{pp}$.

Hampson, G.F. (1894). Fauna of British India including Ceylon and Burma, 
Moths. Vol. II. Taylor and Francis, London, xxviii + 546pp.

Hampson, G.F. (1895). Fauna of British India including Ceylon and Burma, Moths. Vol. IV. Taylor and Francis, London, xxiii + 588pp.

Hampson, G.F. (1896). Fauna of British India including Ceylon and Burma, Moths. Vol. V. Taylor and Francis, London, xxviii + 594pp.

Hodges, R.W. (1978). Gelechioidea (in part): Cosmopterigidae. In Dominick, R.B., T. Dominick, D.C. Ferguson, J.G. Franclemont, R.W. Hodges \& E.G. Munroe (eds.). The Moths of America North of Mexico. E. W. Classey and The Wedge Entomological Research Foundation, London, ix +166 pp., 6 pls.

Hodges, R.W. (1998). The Gelechioidea, pp. 131-158. In: Kristensen, N.P. (ed.), Lepidoptera, Moths and Butterflies 1. Handbuch der Zoologie / Handbook of Zoology IV/35. Walter de Gruyter, Berlin \& New York.

Janse, A.J.T. (1954). Gelechiidae. The Moths of South Africa 5(2): 332384 .

Klots, A.B. (1970). Taxonomists Glossary of Genitalia in Insects Munksasard, Copenhagen Lepidoptera, pp. 115-139 in Tuxen.

Landry, J.F. \& B. Landry (1994). A technique for setting and mounting microlepidoptera. Journal of Lepidopterists Society 48(3): 205-227.

Lindquist, O.H. (1956). A technique for pinning and spreading small microlepidoptera. Can Ent. 138(1) :24-25.

Meyrick, E. (1905). Descriptions of Indian Microlepidoptera. Journal of the Bombay Natural History Society 16: 580-619.

Lovovsky, A.L. (1996). The diversity of the Oecophoridae fauna in the boreal and temporate zones of Eurasia (Lepidoptera). Acta Zoologica Fennica 200: 38.

Meyrick, E. (1894). On a collection of Lepidoptera from upper Burma by Edward Meyrick. Transactions of the Entomological Society of London 1: $1-29$.

Meyrick, E. (1905) Descriptions of Indian Microlepidoptera. Journal of the Bombay Natural History Society 16: 580-619.

Meyrick, E. (1907) Descriptions of Indian Microlepidoptera. Journal of the Bombay Natural History Society 17: 730-754, 976-994.

Meyrick, E. (1908). Descriptions of Indian Microlepidoptera. Journal of the Bombay Natural History Society, 18: 137-160, 437-460, 613$638,806-832$.

Meyrick, E. (1908a). New Micro-Lepidoptera from India and Burma. Records of Indian Museum 12: 3295-400.

Meyrick, E. (1909). Descriptions of Indian Microlepidoptera. Journal of the Bombay Natural History Society 19: 410-437, 582-607.

Meyrick, E. (1910). Descriptions of Indian Microlepidoptera. Journal of the Bombay Natural History Society 20: 143-168, 435-462, 706-736.

Meyrick, E. (1911). Descriptions of Indian Microlepidoptera. Journal of the Bombay Natural History Society 21: 104-131, 852-877.
Meyrick, E. (1912-1916). Exotic Microlepidoptera, E.W. Classey, Hampton, Middlesex, 1: 1-640.

Meyrick, E. (1913). Description of Indian Microlepidoptera. Journal of the Bombay Natural History Society 22: 771-781.

Meyrick, E. (1914). Descriptions of Indian Microlepidoptera. Journal of the Bombay Natural History Society 23: 118-130.

Meyrick, E. (1916-1923). Exotic Microlepidoptera. E.W. Classey, Hampton, Middlesex, 2: 1-640.

Meyrick, E. (1923-1930). Exotic Microlepidoptera. E.W. Classey, Hampton, Middlesex, 3: 1-640.

Meyrick, E. (1930-1936) Exotic Microlepidoptera. E.W. Classey, Hampton, Middlesex, 4: 1-642.

Mikkola, K. (1986). Tower spreading, a handy method for provisional field preparation for microlepidoptera. Nota entomológica 66: 101102 .

Moriuti, S., T. Saito \& A. Lewvanich (1985). Thai species of Periacma Meyrick and its allied two new genera (Lepidoptera: Oecophoridae). Bulletin of University of Osaka Prefecture Series (B) 37: 19-50.

Nye, I.W.B. \& D.S. Fletcher (1991). The generic names of Moths of the world. Natural History Museum Publications 6: 1-368.

Park, K.T. (1995). Gelechiidae of Taiwan 1. Review of Anarsia, with descriptions of four new species (Lepidoptera : Gelechioidea). Tropical Lepidoptera 6(1): 55-66.

Robinson, G.S. (1976). The preparation of slides of Lepidoptera genitalia with special reference to microlepidoptera. Entomologists Gazette 27(2): 127-132.

Robinson, G.S., K.R. Tuck and M. Shaffer (1994). A field guide to the smaller moths of South-East Asia. Malaysian Nature Society, Malasia, 308 pp + pls. 1-32.

Roonwal, M.L., R.N. Mathur, G.D. Bhasin, P.N. Chatterjee, P.K. SenSharma, B. Singh, A. Chandra, R.S. Thapa \&K. Krishna (1964). A systematic catalogue of the main identified entomological collection at the Forest Research Institute, Dehradun, Parts 22-38, 197-537.

Tagestad, A.D. (1974). A technique for mounting microlepidoptera. Journal of the Kansas Entomological Society 47: 26-30.

Ueda, T. (1995). The genus Helcystogramma (Lepidoptera, Gelechiidae) of Japan. Japanese Journal of Entomology 63(2): 377-387.

Ueda, T. and Moriuti, S. (1996). Three new species of the genus Periacma from Nepal (Lepidoptera: Oecophoridae). Bulletin of University of Osaka Prefecture Series (B) 48: 19-24.

Zimmerman, E.C. (1978). Microlepidoptera. Ins. Hawaii, Vol. 9. University Press of Hawaii, Honololu, xviii + 1903pp. 